\title{
Reseña de libro: Violencia, espionaje y represión estatal. Seis estudios de caso sobre el pasado reciente argentino de Débora D’Antonio (comp.) $)^{1}$
}

\author{
Irma Colanzi \\ Universidad Nacional de La Plata, Argentina \\ irma.colanzi@gmail.com
}

Hace más de una década se planteaba en los debates de la historia reciente los desafíos metodológicos de la construcción de conocimiento desde el presente. Florencia Lewin y Marina Franco (2007) nos proponían una agenda de trabajo de este campo de estudios, cuyo interés principal se orientaba a la disputa sobre las voces y las fuentes. En el libro Violencia, espionaje y represión estatal, que reúne una valiosa compilación de trabajos sobre investigaciones con novedosos trabajos de campo, Déborah D'Antonio reúne aportes de investigaciones que configuran los nuevos desafíos del campo y una propuesta caracterizada por una gran rigurosidad metodológica que apunta a nuevos interrogantes sobre el pasado reciente en Argentina y la región.

Uno de los grandes aportes del libro es proponer una agenda de trabajo en los espacios de mayor dificultad al momento de acceder a documentos y experiencias relatadas por sus protagonistas. Los/as autores/as delimitan aspectos que no habían sido explorados hasta el momento como el impacto de la represión en los/ as trabajadores/as del Estado, las lógicas de impunidad de las burocracias estatales, las políticas represivas y sus articulaciones en la región.

Los/as autores/as nos proponen una nueva forma de comprender la violencia del Estado, su lugar e importancia en el pasado reciente. De igual manera, nos invitan a problematizar las continuidades de dichas lógicas en la actualidad, delimitando prácticas represivas entre los gobiernos constitucionales y de facto en el período 1955 y 1983.

Dentro de los enfoques que atraviesan la lectura del libro se hallan las preguntas en torno al género y a la situación de niños/as y adolescentes, en las prácticas represivas y la militarización de diferentes sectores estatales (poder judicial, políticas del poder ejecutivo).

En el primer capítulo Débora D'Antonio realiza un recorrido sobre la experiencia del "Camarón", indagando sobre las estrategias y discursos jurídicos de los/as abogados/as en el Poder Judicial. Se destacan las preguntas agudas y el uso de una triangulación metodológica por parte de la autora, que involucra fuentes de las burocracias jurídicas: libros de Mesa de Entradas de la Cámara Federal en lo penal, fallos del mencionado tribunal citados en publicaciones jurídicas, fuentes periodísticas (Diario La Opinión) y entrevistas que constituyen un aporte original a la problemática objeto de análisis

La autora propicia un debate en torno a las continuidades jurídicas en diferentes regímenes constitucionales, y la colaboración de la justicia penal con la militar. Es significativa la referencia a Juan Bautista Yofre, ex director de la SIDE (Secretaria de Inteligencia del Estado) que refiere que la experiencia de la Cámara Federal en lo penal de la Nación constituyó "la gran oportunidad que tuvimos los argentinos de combatir el fenómeno subversivo con la ley en la mano" (Yofre, 2009: 7. En D'Antonio, 2018: 2).

El análisis de las sentencias de la Cámara da cuenta de una recuperación de la legislación represiva preexistente frente a las acciones de la disidencia política.

La referencia a los fallos de la Cámara antes mencionada se aprecian en el caso de Carlos Mosquera, profesor de Física de la Universidad Nacional de La Plata, con un importante rol en la creación del gremio docente de la Facultad de Ciencias Exactas, miembro del Partido Comunista Revolucionario (PCR). Mosquera fue 
detenido y tortura en diferentes dependencias policialas de La Plata. Mosquera estuvo detenido por más de un año y obtuvo su libertad por la presión popular en la jornada conocida como el Devotazo.

En las tramas de la justicia también se analiza el rol de los/as abogados/as defensores, con diferentes estrategias frente a sus defendidos. Estas acciones se vinculan hasta con el manejo de rumores, como el de la posibilidad de que Ortega Peña, uno de los defensores más radicalizados de la época podría llegar a ser el Ministro de Justicia. Esto tuvo impacto en el logro de varias excarcelaciones.

En el segundo capítulo Ariel Eidelman analiza la actividad paraestatal en la Argentina a principios de los años setenta, desarrollada durante los gobiernos peronistas entre mayo de 1973 y marzo de 1976 (Triple A y otros grupos). Las fuentes que revisa el autor son periodísticas.

En cuanto al alcance regional del análisis propuesto por Eidelman se identifican las ciudades de Buenos Aires, La Plata y Córdoba. En tal sentido, se visualiza el abordaje de un aspecto vacante en los estudios de la historia reciente como es el caso de la Concentración Nacional Universitaria (CNU), que operó desde 1967 en La Plata, Bahía Blanca y Mar del Plata.

El autor analiza la experiencia represiva del secuestro y su institucionalización, a través de los aportes de la prensa. La actividad represiva paraestatal convivía con las lógicas judiciales, ya analizadas en el primer capítulo de la compilación.

En el tercer capítulo Debora D'Antonio revisa nuevamente el aporte del fondo documental del campo jurídico, a fin de analizar el impacto de la dictadura en la clase trabajadora estatal. La autora revisa las cesantías, suspensiones y renuncias forzadas como mecanismos represivos, que por un lado, se sostienen en las distintas administraciones peronistas, entre julio de 1973 y marzo de 1976; y por otro lado, se asocia a un control represivo cada vez más amplio y sistemático en el ámbito laboral.

El decreto Ley de Prescindibilidad ( $\left.\mathrm{N}^{\circ} 20.549\right)$ es el hilo conductor del análisis que propone la autora, por medio de la revisión de leyes, decretos presidenciales, fallos judiciales, el diario de sesiones del parlamento del último tercio del año 1973 y artículos puntuales de la prensa periódica a efectos de analizar los debates acerca de la prescindibilidad en el empleo público.

D'Antonio aborda la prescindibilidad en vínculo con estrategias y políticas represivas que impactaron a gremios y sindicatos. Además de la contribución en el abordaje de esta problemática, la autora propone un análisis con perspectiva de género. Señala que no existió por parte de las fuerzas armadas y de seguridad ninguna deferencia en términos de género para desaparecer a distintas mujeres con embarazos en curso. Esto se produjo en coexistencia con la actividad de generización de la tortura y en especial el doble ensañamiento que existió hacia las mujeres militantes por su disidencia frente a los roles establecidos por la matriz sexogenérica.

En el cuarto capítulo de la compilación, Facundo Fernández Barrio propone un recorrido por las tramas del Servicio Exterior en la represión a la Contraofensiva de Montoneros en Brasil (1978 - 1980). El autor caracteriza la cooperación represiva del Estado paralelo y profundiza la trama legal que configuró la violencia de estado, aspecto que también constituye un área de vacancia de la Historia reciente.

Por medio del análisis de la "operación Gringo", Fernández Barrio interroga acerca de las acciones de sabotaje frente a la contraofensiva de Montoneros. El autor propone una sistematización normativa de la faz pública del estado, mientras convive con acciones de un estado represor.

En el capítulo quinto Melisa Slatman propone una radiografía del dispositivo represivo argentino, en su carácter dual, con una faz legal y pública y una clandestina.

Las burocracias estatales aparecen nuevamente en línea con los dispositivos de inteligencia, que actúan como reaglutinantes del dispositivo represivo.

En consonancia con el análisis de las prácticas de las burocracias estatales, en el último capítulo Natalia Casola plantea diferentes preguntas en torno a la creación de la Escuela de Inteligencia Policial Héctor Ramos. La autora reconstruye el funcionamiento de la Dirección de Inteligencia resituando su lugar. 
Casola delimita una continuidad de los aparatos de inteligencia en democracia. En clave de género, la autora revisa el lugar de las mujeres en las fuerzas. En un contexto de reforzamiento del terror se obligó a la policía a la profesionalización para guerra contra la subversión, y por ello obligó a la policía a utilizar todo el personal disponible indistintamente a su género.

La compilación que presenta D'Antonio constituye un aporte de gran valor para los estudios de la historia reciente y proyecta nuevos interrogantes que exigen estrategias metodológicas acordes a estos nuevos desafíos en la historia reciente.

\section{Notas}

1 D'Antonio, Débora. (comp.). (2018). Violencia, espionaje y represión estatal. Seis estudios de caso sobre el pasado reciente argentino. Buenos Aires: Imago Mundi 